\title{
Arsenic trioxide-induced cell apoptosis and cell cycle arrest are potentiated by 1,25-dihydroxyvitamin D3 in human leukemia K562 cells
}

\author{
YA-LI ZHANG ${ }^{1}$, SHU-KAI QIAO ${ }^{2}$, XIAO-NAN GUO $^{2}$, JIN-HAI REN ${ }^{2}$ and JING-NAN ZHANG ${ }^{2}$ \\ Departments of ${ }^{1}$ General Practice and ${ }^{2}$ Hematology, The Second Hospital of Hebei Medical University, \\ Shijiazhuang, Hebei 050000, P.R. China
}

Received November 11, 2020; Accepted March 25, 2021

DOI: $10.3892 / \mathrm{ol} .2021 .12770$

\begin{abstract}
The interaction between 1,25-dihydroxyvitamin [1,25(OH)2D3] and vitamin D receptor (VDR) plays a critical role in regulating cell proliferation and programmed cell death. The present study aimed to investigate the effects of $1,25(\mathrm{OH}) 2 \mathrm{D} 3 \mathrm{in}$ combination with arsenic trioxide $\left(\mathrm{As}_{2} \mathrm{O}_{3}\right)$ on the proliferation and cell cycle of a K562 leukemia cell

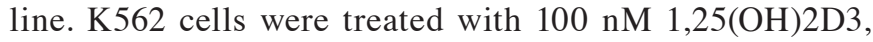
$2.5 \mu \mathrm{M} \mathrm{As} \mathrm{O}_{3}$, and $100 \mathrm{nM} 1,25(\mathrm{OH}) 2 \mathrm{D} 3$ combined with $2.5 \mu \mathrm{M} \mathrm{As} \mathrm{O}_{3}$. Cell proliferation was evaluated by the 3-(4,5-dimethylthiazol-2-yl)-5-(3-carboxymethoxyphenyl)-2(4-sulfophenyl)-2H-tetrazolium, inner salt/phenazine ethosulfate method. Cell cycle progression and apoptosis were detected by flow cytometry. The expression levels of genes associated with the cell cycle and apoptosis were analyzed by reverse transcription-quantitative PCR and western blotting analyses. The present findings indicated that combined treatment of $1,25(\mathrm{OH}) 2 \mathrm{D} 3$ and $\mathrm{As}_{2} \mathrm{O}_{3}$ led to a significant increase in cytotoxicity, apoptotic cell death and $\mathrm{G}_{1}$ cell cycle arrest when compared to those treated with 1,25(OH)2D3 or $\mathrm{As}_{2} \mathrm{O}_{3}$ alone. The downregulation of the $\mathrm{Bax} / \mathrm{Bcl}-2$ ratio and decreased survivin expression may be involved in combined treatment-mediated apoptosis. $G_{0} / G_{1}$ cell cycle arrest induced by combined treatment was associated with the activation of p21 and p27. In addition, the increased expression of VDR was found to participate in the anticancer effect of combination treatment. The data suggested that the combination of 1 , $25-(\mathrm{OH})_{2} \mathrm{D}_{3}$ and $\mathrm{As}_{2} \mathrm{O}_{3}$ had clear synergistic effects on the inhibition of $\mathrm{K} 562$ cell proliferation, which could provide a novel therapeutic approach for the treatment of acute myeloid leukemia.
\end{abstract}

Correspondence to: Professor Shu-Kai Qiao, Department of Hematology, The Second Hospital of Hebei Medical University, 215 Heping Western Road, Shijiazhuang, Hebei 050000, P.R. China E-mail: saidesa@163.com

Key words: 1,25-dihydroxyvitamin D3, arsenic trioxide, K562, apoptosis, cell cycle

\section{Introduction}

The vitamin D receptor (VDR), as a member of the nuclear receptor superfamily, is essential for initiating the intranuclear signaling pathways that are activated by the active metabolite of vitamin D. 1,25-dihydroxyvitamin [1,25(OH)2D3] is the biologically active form of vitamin D3, which directly or indirectly controls hundreds of genes in a cell- and tissue-specific manner $(1,2)$. It is widely accepted that $1,25(\mathrm{OH}) 2 \mathrm{D} 3$ plays a critical role in the metabolism of calcium; however, little is known about the role of other biological functions of $1,25(\mathrm{OH}) 2 \mathrm{D} 3$, such as the inhibition of cell proliferation, induction of differentiation, cell cycle and apoptosis regulation, suppression of angiogenesis and participation in inflammatory processes. Epidemiological evidence has revealed an association between vitamin D status and the risk of developing cancer $(3,4)$. Different studies also indicated that $1,25(\mathrm{OH}) 2 \mathrm{D} 3$ has a potent anticancer effect in vitro and in vivo (5-7). Furthermore, it was shown in a previous study that VDR expression was markedly decreased when the tumor disease stage advanced (8). Although, to the best of our knowledge, the molecular mechanisms of the anticancer activity of $1,25(\mathrm{OH}) 2 \mathrm{D} 3$ have not yet been fully elucidated, the ability of $1,25(\mathrm{OH}) 2 \mathrm{D} 3$ to inhibit cancer development is considered to be mediated by a combination of different pathways. In view of its potent antiproliferative and pro-differentiation action, and the presence of the VDR in a large variety of myeloid leukemia cells, 1,25(OH)2D3 could be considered a promising drug to treat myeloid malignancies (9).

It is well known that arsenic trioxide $\left(\mathrm{As}_{2} \mathrm{O}_{3}\right)$ has been successfully used to treat acute promyelocytic leukemia (APL) in traditional medicine (10). Recently, it has been approved by the US Food and Drug Administration for the treatment of relapsed/refractory APL (11). Studies have revealed that $\mathrm{As}_{2} \mathrm{O}_{3}$ exerts proapoptotic effects, not only in APL cells, but also in other hematopoietic malignancies and solid tumors $(12,13)$. The underlying mechanisms of the antitumor activity of $\mathrm{As}_{2} \mathrm{O}_{3}$ have been associated with the induction of tumor apoptosis and inhibition of cell proliferation by promoting the production of reactive oxygen species (14). However, whether 1,25(OH)2D3 and $\mathrm{As}_{2} \mathrm{O}_{3}$ exert synergistic effects on the proliferation and differentiation of leukemia cells remains unknown. 
In the present study, the antitumor effect of 1,25(OH)2D3 combined with $\mathrm{As}_{2} \mathrm{O}_{3}$ was investigated, and the underlying molecular mechanisms were determined using a K562 cell line established from human chronic myelogenous leukemia cells in blast crisis.

\section{Materials and methods}

Cell line, cell culture and reagents. The K562 cell line was purchased from The Cell Bank of Type Culture Collection of The Chinese Academy of Sciences. Cells were cultured in RPMI-1640 medium (Thermo Fisher Scientific, Inc.) supplemented with $10 \%$ fetal bovine serum (FBS; Cytiva), $100 \mu \mathrm{g} / \mathrm{ml}$ penicillin, $10 \mu \mathrm{g} / \mathrm{ml}$ streptomycin, and $2 \mathrm{mmol} / \mathrm{l} \mathrm{L-glutamine}$. Cells were maintained in $\log$ phase growth at $37^{\circ} \mathrm{C}$ in a humidified atmosphere containing $5 \% \mathrm{CO}_{2}$.

$1,25(\mathrm{OH})_{2} \mathrm{D}_{3}$ (Merck KGaA), also known as calcitriol, was dissolved in $100 \%$ ethanol at a concentration of $5 \times 10^{-4} \mathrm{~mol} / 1$ as a stock solution and stored at $20^{\circ} \mathrm{C}$ for use in the following experiments. For all experiments, dilutions of the stock solution were made in RPMI-1640 medium without FBS. The maximum concentration of ethanol in the culture did not exceed $0.1 \%$. $\mathrm{As}_{2} \mathrm{O}_{3}$ was purchased from Heilongjiang Harbin Yida Pharmaceutical Co., Ltd.

Optimaldrug concentration screening and evaluation. Inhibition rate of the cell proliferation in K562 cells was measured using a 3-(4,5-dimethylthiazol-2-yl)-5-(3-carboxymethoxyphenyl)-2-( 4-sulfophenyl)-2H-tetrazolium, inner salt/phenazine ethosulfate (MTS/PES) assay. The cytotoxic effects of $1,25(\mathrm{OH})_{2} \mathrm{D}_{3}$ on K562 cells were examined by treating 4,000 cells/well with $0.1 \%$ ethanol and 0, 10, 50, 100 or $200 \mathrm{nM} 1,25(\mathrm{OH}) 2 \mathrm{D} 3$ for $72 \mathrm{~h}(15)$, and then analyzed using a MTS/PES assay with the absorbance measured at a wavelength of $490 \mathrm{~nm}$. For arsenic trioxide, no concentration gradient experiment was performed; the optimal concentration of $2.5 \mu \mathrm{M}$ was obtained from the literature (16).

Cell proliferation assay. Cell proliferation was determined in 96-well plates using an MTS/PES assay, according to the manufacturer's instructions. Briefly, following treatment with $100 \mathrm{nM}$ $1,25(\mathrm{OH})_{2} \mathrm{D}_{3}$ and $2.5 \mu \mathrm{M} \mathrm{As}_{2} \mathrm{O}_{3}$, alone or combined, $\mathrm{K} 562$ cells were seeded in 96-well plates at a density of 4,000 cells/well. The same number of untreated cells were seeded as the control. Cultures were set up in triplicate and maintained at $37^{\circ} \mathrm{C}$ in a humidified atmosphere with $5 \% \mathrm{CO}_{2}$. Following 24, 48, 72, 96 or $120 \mathrm{~h}$ of treatment, $10 \mu 1 \mathrm{MTS} / \mathrm{PES}$ (10 mg/ml; Promega Corporation) was added into each well for an additional $6 \mathrm{~h}$ incubation. A microplate reader was used to measure the absorbance value at $490 \mathrm{~nm}$ for each well, which represented K562 cell proliferation.

Assessment of apoptosis and cell cycle analysis. The apoptosis assay of K562 cells was performed using an Annexin V/propidium iodide (PI) apoptosis assay kit (BioLegend,Inc.), according to the manufacturer's instructions. Briefly, the cells were harvested and washed twice with cold phosphate-buffered saline (PBS). Cells were then resuspended in $1 \mathrm{X}$ binding buffer at a concentration of $1 \times 10^{6}$ cells $/ \mathrm{ml}$. A total of $100 \mu \mathrm{l}$ of the solution was transferred to a 5-ml culture tube with $5 \mu \mathrm{l}$ Annexin V-FITC and $10 \mu \mathrm{l}$ PI $(50 \mathrm{mg} / \mathrm{ml})$. Cells were gently vortexed and incubated for $15 \mathrm{~min}$ at room temperature in the dark. Following the addition of $400 \mathrm{ml}$ of binding buffer, these cells were analyzed by flow cytometry (FCM). Annexin $\mathrm{V}^{-}$and $\mathrm{PI}^{-}$cells were considered viable cells, Annexin $\mathrm{V}^{+}$and $\mathrm{PI}^{-}$cells were considered early apoptotic cells and Annexin $\mathrm{V}^{+}$and $\mathrm{PI}^{+}$cells were considered late apoptotic cells.

Cell cycle distribution was determined by staining DNA with PI, as previously described (17). Briefly, $5 \times 10^{6}$ K562 cells were collected from cultures, washed twice with PBS and fixed in $70 \%$ pre-cold ethanol at $4^{\circ} \mathrm{C}$ overnight. The fixed cells were then collected and resuspended in PBS, containing $50 \mathrm{mg} / \mathrm{ml} \mathrm{PI}$ and $100 \mu \mathrm{g} / \mathrm{ml}$ DNase-free RNase A. Cells were incubated for $1 \mathrm{~h}$ at room temperature and then analyzed by FCM.

Reverse transcription-quantitative PCR (RT-qPCR). K562 cells from each experimental group were collected and washed three times with cold PBS, and then total cell mRNA was extracted using TRIzol ${ }^{\circledR}$ reagent (Invitrogen; Thermo Fisher Scientific, Inc.), according to the manufacturer's instructions. cDNA was synthesized from $2 \mu \mathrm{g}$ total RNA using a first-strand cDNA synthesis kit (Thermo Fisher Scientific, Inc.). The PCR amplification protocol was as follows: Denaturation at $94^{\circ} \mathrm{C}$ for $10 \mathrm{~min}$, followed by 40 cycles of $94^{\circ} \mathrm{C}$ for $15 \mathrm{sec}, 58^{\circ} \mathrm{C}$ for $30 \mathrm{sec}$ and $72^{\circ} \mathrm{C}$ for $40 \mathrm{sec}$. The mRNA expression levels of VDR, Bcl-2, survivin, Bax, p21, p27 and $\beta$-actin were detected using ABI 7000 (Thermo Fisher Scientific, Inc.) and Talent qPCR PreMix (SYBR-Green) (Tiangen Biotech Co., Ltd). The relative quantification based on the relative expression of target genes was calculated using the $2^{-\Delta \Delta \mathrm{Cq}}$ method (18). The PCR primers were designed based on the corresponding gene structure, and the sequences are listed in Table I. RT-qPCR was performed in triplicate.

Western blot analysis. Following various treatments with $100 \mathrm{nM} 1,25(\mathrm{OH}) 2 \mathrm{D} 3$ and $2.5 \mu \mathrm{M}$ As2O3, alone or combined, K562 cells were collected and washed three times with pre-cooled PBS. The proteins were extracted using RIPA buffer (Thermo Fisher Scientific, Inc.) and quantified using a bicinchoninic acid protein assay kit (Thermo Fisher Scientific, Inc.). Proteins were separated via SDS-PAGE (15\% gel) and transferred to a polyvinylidene difluoride membrane. The membrane was blocked with $5 \%$ non-fat milk in Tris-buffered saline containing $0.1 \%$ Tween-20 (TBST) at $37^{\circ} \mathrm{C}$ for $2 \mathrm{~h}$, and subsequently incubated with the primary antibodies mouse anti-VDR (1:1,000; cat. no. sc13133), mouse anti-Bcl-2 (1:1,000; cat. no. sc7382), mouse anti-survivin (1:1,000; cat. no. sc17779), mouse anti-Bax (1:1,000; cat. no. sc7480), mouse anti-p21 (1:1,000; cat. no. sc6246), mouse anti-p27 $(1: 1,000$; cat. no. sc1641) and mouse anti- $\beta$-actin $(1: 1,000$; cat. no. sc69879) (all from Santa Cruz Biotechnology, Inc.) at $4^{\circ} \mathrm{C}$ overnight. After five more washes with TBST, the blots were incubated with the horseradish peroxidase-conjugated rabbit anti-mouse $\operatorname{IgG}$ (1:5,000; cat. no. ab6728; Abcam) for $1 \mathrm{~h}$ at room temperature. The immunoreactive bands were visualized by enhanced chemiluminescence (ECL) on a Kodak Image Station $4000 \mathrm{~mm}$ Pro system (Kodak Corporation). The quantitative data from bands were analyzed using the Image Tool system (version 3.0; www.bio-soft.net).

Statistical analysis. All statistical data are presented as the mean \pm standard deviation. The treatment effects among different 
Table I. Reverse transcription-quantitative PCR primers.

\begin{tabular}{lll}
\hline Gene & Direction & \multicolumn{1}{c}{ Sequence } \\
\hline VDR & Sense & 5'-AGCTGGCCCTGGCACTGACTCTGCTCT-3' \\
& Antisense & 5'-ATGGAAACACCTTGCTTCTTCTCCCTC-3' \\
Bcl-2 & Sense & 5'-ATCGCCCTG TGGATGACTGAG-3' \\
& Antisense & 5'-CAGCCAGGAGAAATCAAACAGAGG-3' \\
Survivin & Sense & 5'-CCCTGCCTGGCAGCCCTTTC-3' \\
& Antisense & 5'-CTGGCTCCCAGCCTTCCA-3' \\
Bax & Sense & 5'-GGACGAACTGGACAGTAACATGG-3' \\
p21 & Antisense & 5'-GCAAAGTAGAAAAGGGCGACAAC-3' \\
& Sense & 5'-GCAGACCAGCATGACAGATTT-3' \\
p27 & Antisense & 5'-GGATTAGGGCTTCCTCTTGGA-3' \\
& Sense & 5'-CCTCTTCGGCCCGGTGGAC-3' \\
3-actin & Antisense & 5'-TTTGGGGAACCGTCTGAAAC-3' \\
& Sense & 5'-TCTGGCACCACACCTTCTACAATG-3' \\
& Antisense & 5'-AGCACAGCCTGGATAGCAACG-3'
\end{tabular}

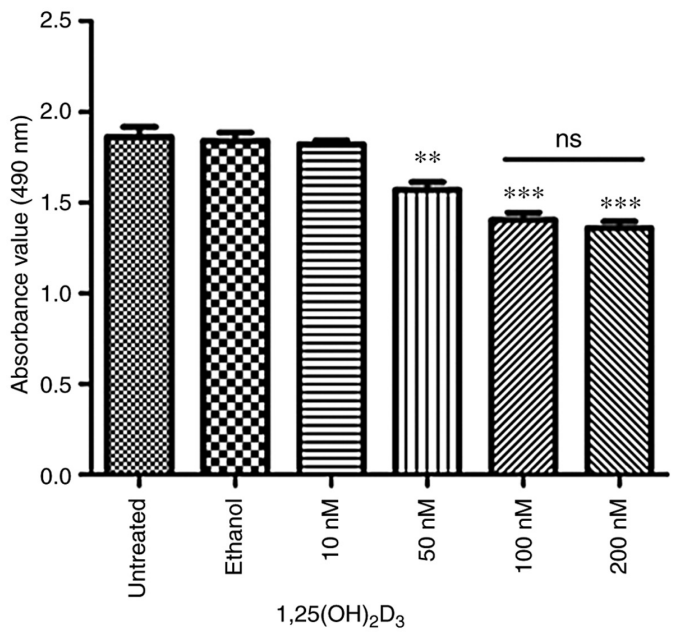

Figure 1. Proliferation of K562 cells is suppressed by 1,25(OH)2D3 in a dose-dependent manner. K562 cells at an initial density of 4,000 cells/well were treated with different concentrations of $1,25(\mathrm{OH}) 2 \mathrm{D} 3(10,50,100$ or $200 \mathrm{nM})$ for $72 \mathrm{~h}$, and then analyzed by MTS/PES assay absorbance measured at a wavelength of $490 \mathrm{~nm}$. Untreated, without 1,25(OH)2D3 treatment; ethanol, with $0.1 \%$ ethanol treatment. Data are presented as the mean $\pm \mathrm{SD}$ of three independent experiments. ${ }^{* *} \mathrm{P}<0.01$ and ${ }^{* * *} \mathrm{P}<0.001$ vs. untreated group. 1,25(OH)2D3, 1,25-dihydroxyvitamin; ns, not significant.

groups were compared using one-way analysis of variance and Bonferroni's post hoc test. All analyses were performed using GraphPad Prism version 5.0 (GraphPad Software, Inc.). $\mathrm{P}<0.05$ was considered to indicate a statistically significant difference.

\section{Results}

1,25(OH)2D3 exerts synergistic effects with $\mathrm{As}_{2} \mathrm{O}_{3}$ on the proliferation of $\mathrm{K} 562$ cells. The results of the MTS/PES assay revealed that $1,25(\mathrm{OH}) 2 \mathrm{D} 3$ suppressed the proliferation of K562 cells in a dose-dependent manner (Fig. 1). Since $100 \mathrm{nM}$ $1,25(\mathrm{OH}) 2 \mathrm{D} 3$ displayed the most significant anticancer effect on K562 cells, that concentration was selected for subsequent

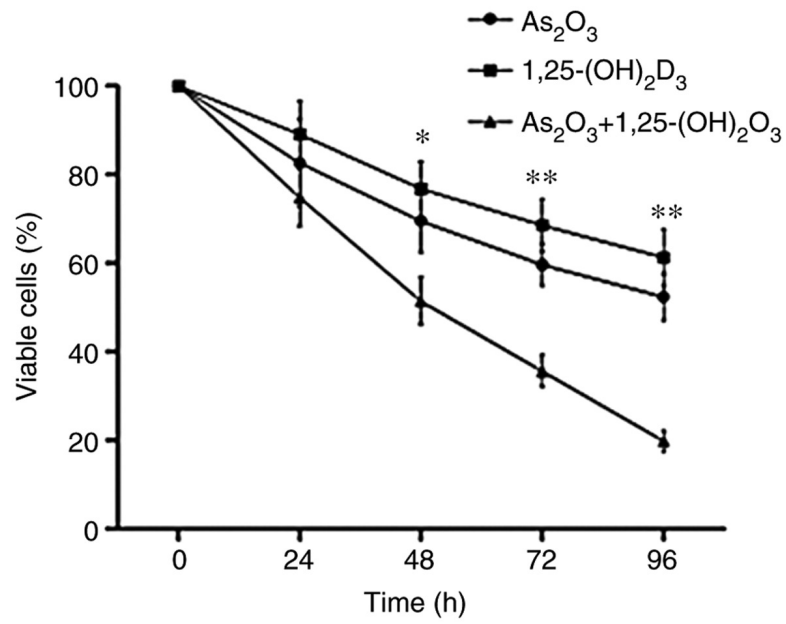

Figure 2. Synergistic effect of $\mathrm{As}_{2} \mathrm{O}_{3}$ and 1,25(OH)2D3 in the treatment of K562 cells. MTS/PES assay results showed that $2.5 \mu \mathrm{M} \mathrm{As}_{2} \mathrm{O}_{3}$ and $100 \mathrm{nM}$ $1,25(\mathrm{OH}) 2 \mathrm{D} 3$ exerted a synergistic inhibitory effect on K562 cells. Data are presented as the mean $\pm \mathrm{SD}$ of three independent experiments. ${ }^{*} \mathrm{P}<0.05$ and ${ }^{* *} \mathrm{P}<0.01$ vs. K562 cells treated with a combination of $\mathrm{As}_{2} \mathrm{O}_{3}$ and 1,25(OH)2D3. $\mathrm{As}_{2} \mathrm{O}_{3}$, arsenic trioxide; 1,25(OH)2D3, 1,25-dihydroxyvitamin.

experiments. The results showed that $100 \mathrm{nM} 1,25(\mathrm{OH}) 2 \mathrm{D} 3$ or $2.5 \mu \mathrm{M} \mathrm{As}_{2} \mathrm{O}_{3}$ alone exerted inhibitory effects on K562 cells. Of note, the inhibition of cell proliferation was more effective with combined treatment than with treatment with $\mathrm{As}_{2} \mathrm{O}_{3}$ or 1,25(OH)2D3 alone (Fig. 2).

1,25(OH)2D3 enhances the $\mathrm{As}_{2} \mathrm{O}_{3}$-induced apoptosis of $\mathrm{K} 562$

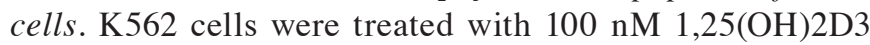
and/or $2.5 \mu \mathrm{M} \mathrm{As}_{2} \mathrm{O}_{3}$ for $72 \mathrm{~h}$. Fig. 3A shows a representative example of apoptotic cells in untreated K562 cells and cells treated with $1,25(\mathrm{OH}) 2 \mathrm{D} 3, \mathrm{As}_{2} \mathrm{O}_{3}$ or a combination of both. The results showed that the percentage ratio of early and late apoptotic cells in the combination group was significantly higher than that in the blank control and 1,25(OH)2D3 or $\mathrm{As}_{2} \mathrm{O}_{3}$ treatment groups $(\mathrm{P}<0.01$; Fig. 3B). 


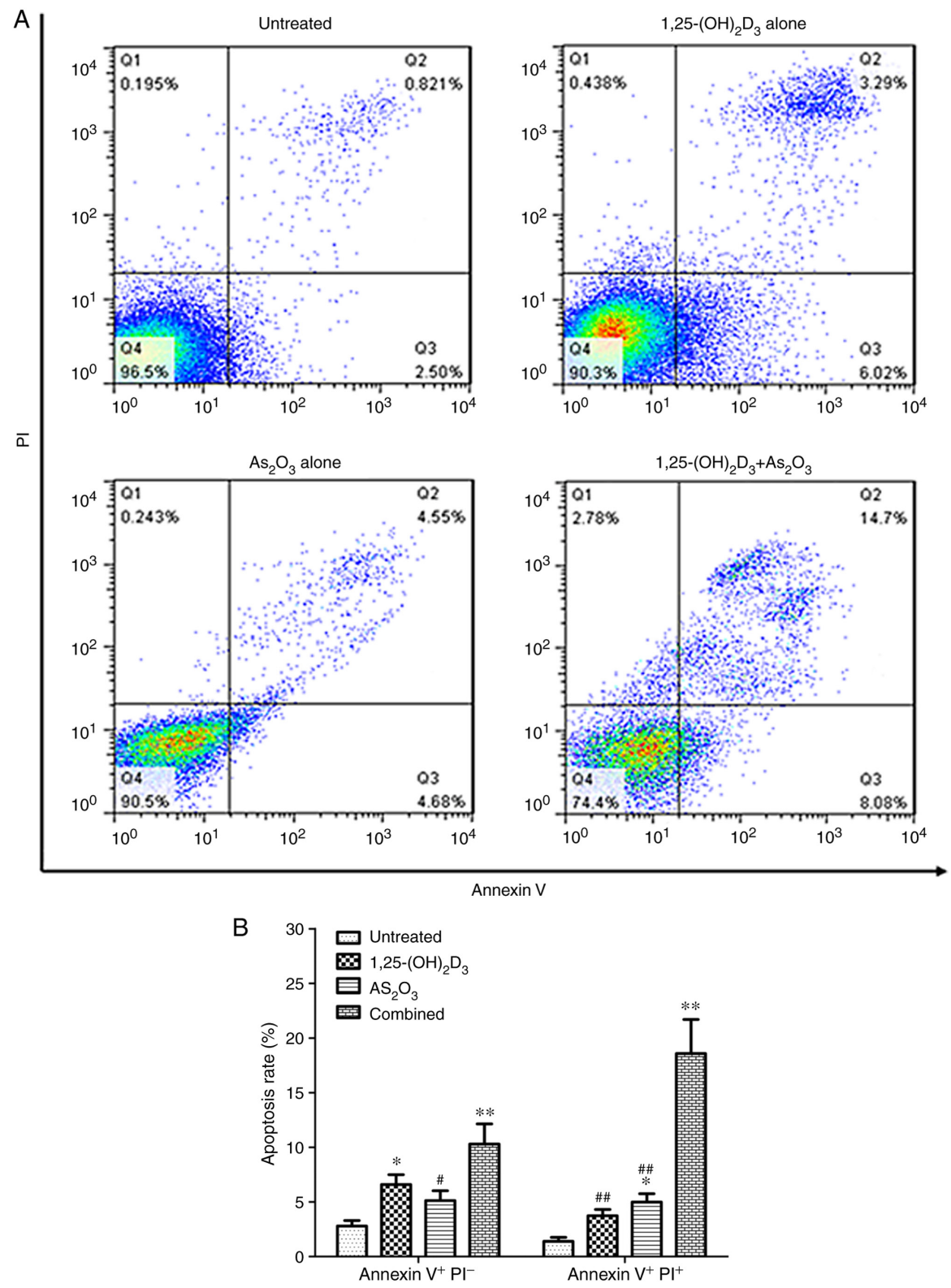

Figure 3. Proportion of apoptotic of $\mathrm{K} 562$ cells following treatment with 1,25(OH)2D3, $\mathrm{As}_{2} \mathrm{O}_{3}$ or a combination of both for $72 \mathrm{~h}$. (A) Representative example of apoptotic cells following Annexin V/PI staining. (B) Comparison of apoptotic rates in each group. Annexin $\mathrm{V}^{+} \mathrm{PI}^{-}$represents early apoptotic cells. Annexin $\mathrm{V}^{+}$ $\mathrm{PI}^{+}$represents late apoptotic cells. Data are presented as the mean $\pm \mathrm{SD}$ of three independent experiments. ${ }^{*} \mathrm{P}<0.05$ and ${ }^{* *} \mathrm{P}<0.01$ vs. control group; ${ }^{*} \mathrm{P}<0.05$ and ${ }^{\# \#} \mathrm{P}<0.01$ vs. combined treatment group. 1,25(OH)2D3, 1,25-dihydroxyvitamin; $\mathrm{As}_{2} \mathrm{O}_{3}$, arsenic trioxide; PI, propidium iodide.

$1,25(\mathrm{OH}) 2 \mathrm{D} 3$ and $\mathrm{As}_{2} \mathrm{O}_{3}$ induce $\mathrm{G}_{1}$ cell cycle arrest. Cell cycle distribution was analyzed via FCM. Fig. 4A shows a representative example of cell cycle distribution in untreated K562 cells and cells treated with $1,25(\mathrm{OH}) 2 \mathrm{D} 3, \mathrm{As}_{2} \mathrm{O}_{3}$ or a combination of both. The results revealed that the combined treatment markedly increased the population of cells in the $\mathrm{G}_{0} / \mathrm{G}_{1}$ phase and significantly decreased the population of cells in the S-phase compared with cells treated with $1,25(\mathrm{OH}) 2 \mathrm{D} 3$ or $\mathrm{As}_{2} \mathrm{O}_{3}$ alone. By contrast, the percentage of cells in the $\mathrm{G}_{2} / \mathrm{M}$ phase was relatively unaffected (Fig. 4B). These data demonstrated that the combined treatment induced significant arrest of cell cycle progression in the $\mathrm{G}_{0} / \mathrm{G}_{1}$ phase.

Effects of $1,25(\mathrm{OH}) 2 \mathrm{D} 3$ and $\mathrm{As}_{2} \mathrm{O}_{3}$ on the expression of apoptosis-related and cycle-regulated genes and proteins. To further investigate the underlying molecular mechanisms of cell proliferation suppression, apoptosis induction and $\mathrm{G}_{0} / \mathrm{G}_{1}$ cell cycle arrest, the mRNA and protein expression levels of VDR, Bcl-2, Bax, survivin, p21 and p27 were analyzed in K562 cells using RT-qPCR and western blot analysis. Fig. 5 presents the relative mRNA quantification of these genes in untreated $\mathrm{K} 562$ cells and cells treated with $1,25(\mathrm{OH}) 2 \mathrm{D} 3, \mathrm{As}_{2} \mathrm{O}_{3}$ or a combination of both. The results revealed that the combined treatment with $1,25(\mathrm{OH}) 2 \mathrm{D} 3$ and $\mathrm{As}_{2} \mathrm{O}_{3}$ resulted in a marked reduction in the levels of Bcl-2 and survivin when compared with untreated cells and $1,25(\mathrm{OH}) 2 \mathrm{D} 3$ or $\mathrm{As}_{2} \mathrm{O}_{3}$ alone, while the levels of the VDR, Bax, p21 and p27 were significantly increased following combined treatment. Representative immunoblots are presented in Fig. 6A. Similar to the observed mRNA expression levels, the protein expression levels of VDR, Bax, p21 and p27 were found to be increased, while the expression 


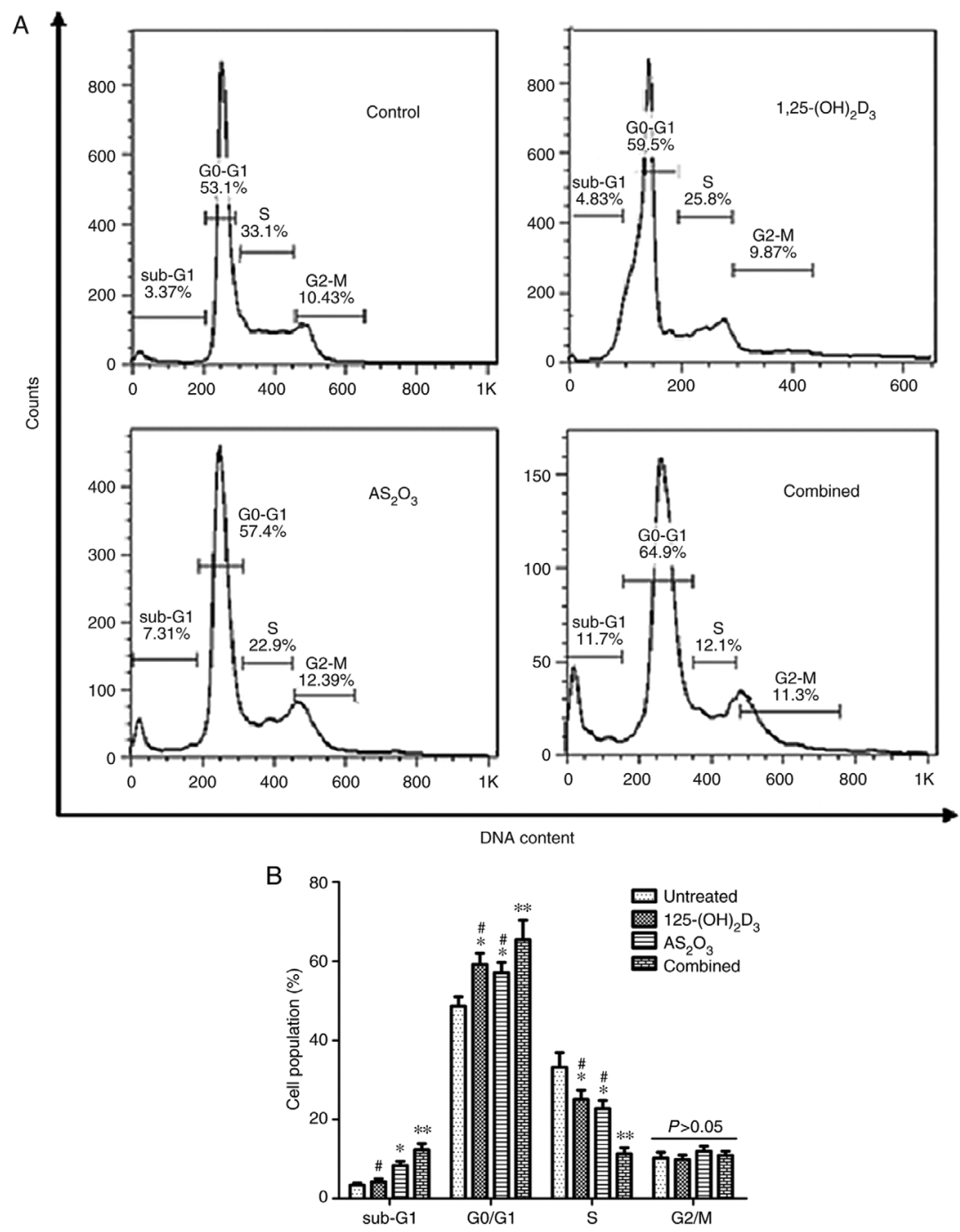

Figure 4. $\mathrm{G}_{1}$ cell cycle arrest is induced by $1,25(\mathrm{OH}) 2 \mathrm{D} 3$ and $\mathrm{As}_{2} \mathrm{O}_{3}$ following treatment with $1,25(\mathrm{OH}) 2 \mathrm{D} 3, \mathrm{As}_{2} \mathrm{O}_{3}$ or a combination of both for $72 \mathrm{~h}$. (A) Representative example of cell cycle distribution in untreated $\mathrm{K} 562$ cells and cells treated with $1,25(\mathrm{OH}) 2 \mathrm{D} 3$, $\mathrm{As}_{2} \mathrm{O}_{3}$, or the combination of both (B) Cell cycle distribution in each group. Data are presented as the mean $\pm \mathrm{SD}$ of three independent experiments. " $\mathrm{P}<0.05$ and ${ }^{* * *} \mathrm{P}<0.01$ vs. control group; ${ }^{\prime} \mathrm{P}<0.05$ vs. combined treatment group. 1,25(OH)2D3, 1,25-dihydroxyvitamin; $\mathrm{As}_{2} \mathrm{O}_{3}$, arsenic trioxide.

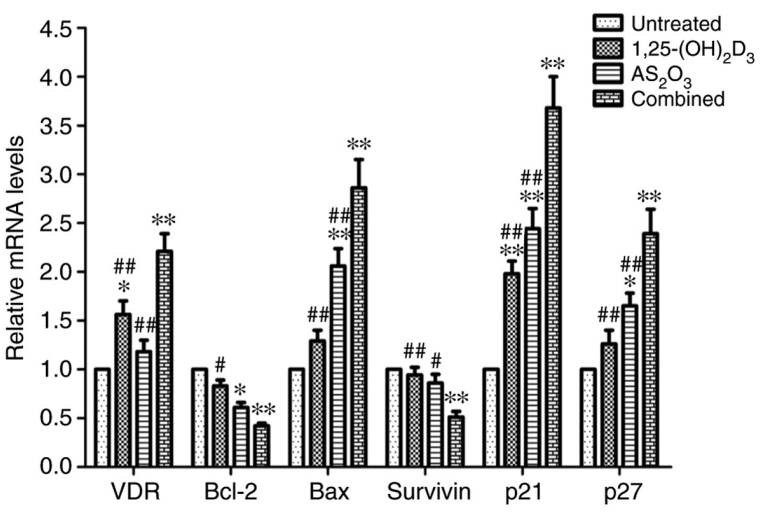

Figure 5. mRNA expression levels of related genes following the treatment of K562 cells with $1,25(\mathrm{OH}) 2 \mathrm{D} 3, \mathrm{As}_{2} \mathrm{O}_{3}$ or a combination of both for $72 \mathrm{~h}$. Data are presented as the mean \pm SD of three independent experiments. ${ }^{*} \mathrm{P}<0.05$ and ${ }^{* *} \mathrm{P}<0.01$ vs. control group; ${ }^{\#} \mathrm{P}<0.05$ and ${ }^{\#} \mathrm{P}<0.01$ vs. combined treatment group. 1,25(OH)2D3, 1,25-dihydroxyvitamin; $\mathrm{As}_{2} \mathrm{O}_{3}$, arsenic trioxide.

levels of Bcl-2 and survivin were found to be significantly decreased (Fig. 6B).

\section{Discussion}

The ability of $1,25(\mathrm{OH}) 2 \mathrm{D} 3$ to induce apoptosis has been demonstrated in various tumor cells. Although, to the best of our knowledge, the mechanisms underlying the apoptotic effects have not yet been fully elucidated, 1,25(OH)2D3 may induce cell death by triggering the intrinsic, mitochondria-dependent pathway (6). According to cell type, $1,25(\mathrm{OH}) 2 \mathrm{D} 3$ can increase the expression levels of proapoptotic factors Bax and $\mathrm{Bcl}-2$ homologous antagonist killer (Bak) and/or decrease their anti-apoptotic equivalents Bcl-2 and B-cell lymphoma-extra large, thus directing the cells towards apoptosis rather than towards survival $(19,20)$. Elucidating the precise molecular mechanism underlying the antiproliferative action of 1,25(OH)2D3 could help identify new biomarkers for targeted treatment with novel vitamin D analogs.

The results of the present study showed that both 1,25( $(\mathrm{OH}) 2 \mathrm{D} 3$ and $\mathrm{As}_{2} \mathrm{O}_{3}$ are reagents that can effectively inhibit the proliferation of $\mathrm{K} 562$ leukemia cells. FCM showed that $\mathrm{As}_{2} \mathrm{O}_{3}$ significantly increased the rate of late apoptotic cells, but had no significant effect on the rate of early apoptotic cells. By contrast, 


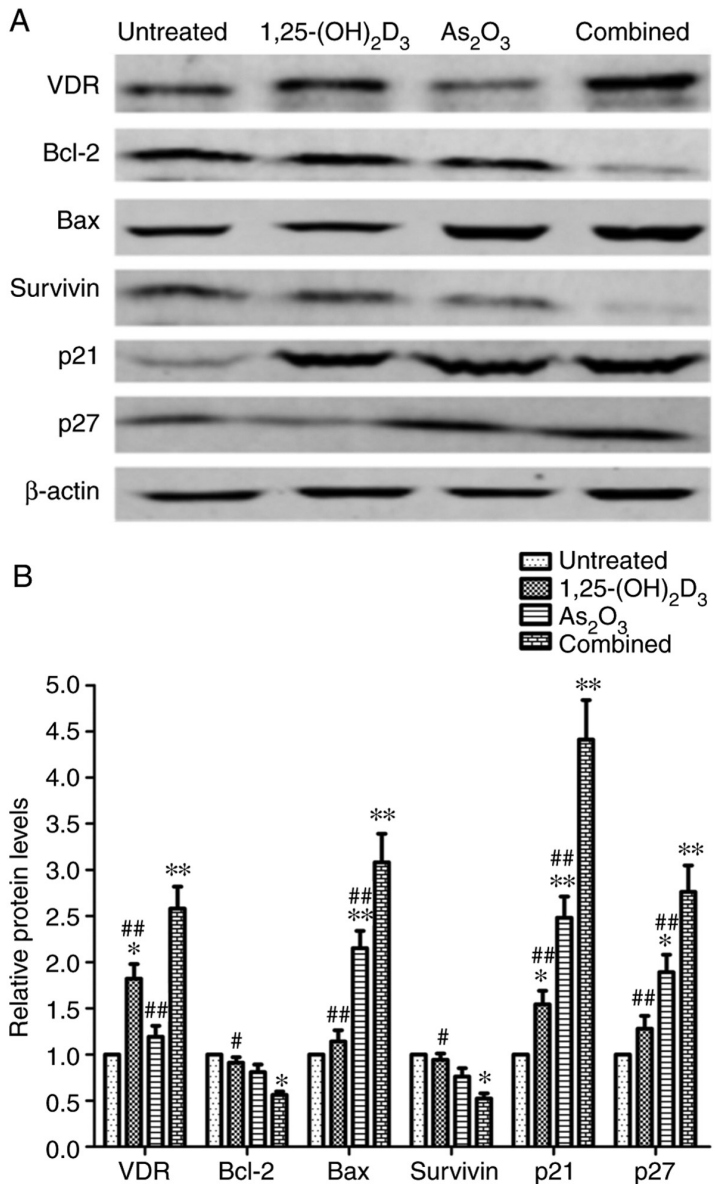

Figure 6. Protein expression levels of related genes following the treatment of $\mathrm{K} 562$ cells with $1,25(\mathrm{OH}) 2 \mathrm{D} 3, \mathrm{As}_{2} \mathrm{O}_{3}$ or a combination of both for $72 \mathrm{~h}$. (A) Representative western blotting images. (B) Comparison of protein expression levels in each group. Data are presented as the mean $\pm \mathrm{SD}$ of three independent experiments. ${ }^{*} \mathrm{P}<0.05$ and ${ }^{* *} \mathrm{P}<0.01$ vs. control group; ${ }^{~} \mathrm{P}<0.05$ and ${ }^{\# \#} \mathrm{P}<0.01$ vs. combined treatment group. 1,25(OH)2D3, 1,25-dihydroxyvitamin; $\mathrm{As}_{2} \mathrm{O}_{3}$, arsenic trioxide.

$1,25(\mathrm{OH}) 2 \mathrm{D} 3$ only increased the rate of early apoptotic cells, but did not affect the rate of late apoptotic cells. When $\mathrm{As}_{2} \mathrm{O}_{3}$ and $1,25(\mathrm{OH}) 2 \mathrm{D} 3$ were combined for the treatment of K562 cells, a synergistic effect was observed. It is well known that apoptosis is regulated by a series of genes. Survivin is a member of the inhibitor of apoptosis family of proteins, which are involved in the inhibition of apoptosis and regulation of the cell cycle (21). Upregulation of survivin promotes tumor progression by inhibiting both the intrinsic and extrinsic pathways of apoptosis, altering sensitivity to antitumor drugs or prolonging the survival of cancer stem cells (22). It has been hypothesized that survivin can also serve as a universal tumor antigen, since it is expressed in the majority of human hematological malignancies and has the potential to trigger immune effector responses (23). The results of the present study indicated that the combined treatment of $1,25(\mathrm{OH}) 2 \mathrm{D} 3$ and $\mathrm{As}_{2} \mathrm{O}_{3}$ may significantly decrease the expression of survivin, while $1,25(\mathrm{OH}) 2 \mathrm{D} 3$ and $\mathrm{As}_{2} \mathrm{O}_{3}$ alone cannot affect its expression. Therefore, blocking the function of survivin through the use of various drugs or molecular approaches is a promising therapeutic strategy for leukemia.

Previous studies have demonstrated that both 1,25(OH)2D3 and $\mathrm{As}_{2} \mathrm{O}_{3}$ can arrest the cell cycle at the $\mathrm{G}_{1}$ phase, probably through the upregulation of one or both of the cyclin-dependent kinase inhibitors (p21 and p27), so as to inhibit the malignant proliferation of K562 cells $(15,16,24)$. In accordance with these results, the data generated in the present study indicated that treatment with $\mathrm{As}_{2} \mathrm{O}_{3}$ and 1,25(OH)2D3 alone caused clear $\mathrm{G}_{1} / \mathrm{S}$ arrest, while the number of cells in the $\mathrm{G}_{2} / \mathrm{M}$ phase was relatively unaffected. Further research showed that the $\mathrm{G}_{1} / \mathrm{S}$ blockade induced by combined treatment with $1,25(\mathrm{OH}) 2 \mathrm{D} 3$ and $\mathrm{As}_{2} \mathrm{O}_{3}$ could upregulate the protein expression of $\mathrm{p} 21$ and p27, while treatment with $1,25(\mathrm{OH}) 2 \mathrm{D} 3$ only upregulated the expression of $\mathrm{p} 21$. In addition, $1,25(\mathrm{OH}) 2 \mathrm{D} 3$ could increase the expression of VDR, while $\mathrm{As}_{2} \mathrm{O}_{3}$ did not affect the expression.

Due to the small amount of experimental conditions in the present study, there are still some limitations to the present study and some aspects that were not investigated. The present study focused on the changes observed from traditional apoptosis and cell cycle-related genes in regard to the underlying anticancer molecular mechanisms. However, the effects of combined treatment on mitochondrial dysfunctions, oxidative stress and regulation of calcium influx are not involved. Future studies could use a reactive oxygen species assay kit to quantify the levels of intracellular reactive oxygen species and apply fluorescent rhodamine derivatives.

Overall, the results of the present study provided evidence that the addition of $1,25(\mathrm{OH}) 2 \mathrm{D} 3$ may increase the therapeutic efficacy of $\mathrm{As}_{2} \mathrm{O}_{3}$, which may in turn decrease adverse effects and initiate a more comprehensive antitumor pathway. This potential method urgently requires further investigation to elucidate the potential therapeutic benefits of a variety of non-APL hematological malignancies.

\section{Acknowledgements}

Not applicable.

\section{Funding}

No funding was received.

\section{Availability of data and materials}

The datasets used and/or analyzed during the present study are available from the corresponding author on reasonable request.

\section{Authors' contributions}

YLZ, JHR, XNG and JNZ performed the research, analysis and interpretation of the data. YLZ and XNG drafted the manuscript and gave final approval of the version to be published. SKQ designed the study and supervised preparation of the manuscript, and provided general support. YLZ and SKQ confirm the authenticity of all the raw data. All authors read and approved the final manuscript.

\section{Ethics approval and consent to participate}

Not applicable.

\section{Patient consent for publication}

Not applicable. 


\section{Competing interests}

The authors declare that they have no competing interests.

\section{References}

1. Christakos S, Dhawan P, Verstuyf A, Verlinden L and Carmeliet G: Vitamin D: Metabolism, molecular mechanism of action, and pleiotropic effects. Physiol Rev 96: 365-408, 2016.

2. Umar M, Sastry KS and Chouchane AI: Role of vitamin D beyond the skeletal function: A review of the molecular and clinical studies. Int J Mol Sci 19: 1618, 2018.

3. Krishnan AV and Feldman D: Mechanisms of the anti-cancer and anti-inflammatory actions of vitamin D. Annu Rev Pharmacol Toxicol 51: 311-336, 2011.

4. Grant WB and Boucher BJ: Randomized controlled trials of vitamin D and cancer incidence: A modeling study. PLoS One 12: e0176448, 2017.

5. Bandera Merchan B, Morcillo S, Martin-Nuñez G, Tinahones FJ and Macías-González M: The role of vitamin D and VDR in carcinogenesis: Through epidemiology and basic sciences. J Steroid Biochem Mol Biol 167: 203-218, 2017.

6. Picotto G, Liaudat AC, Bohl L and Tolosa de Talamoni N Molecular aspects of vitamin D anticancer activity. Cancer Invest 30: 604-614, 2012.

7. Díaz L, Díaz-Muñoz M, García-Gaytán AC and Méndez I: Mechanistic effects of calcitriol in cancer biology. Nutrients 7: 5020-5050, 2015.

8. Campbell MJ and Trump DL: Vitamin D receptor signaling and cancer. Endocrinol Metab Clin North Am 46: 1009-1038, 2017.

9. Kulling PM, Olson KC, Olson TL, Feith DJ and Loughran TP Jr: Vitamin D in hematological disorders and malignancies. Eur J Haematol 98: 187-197, 2017.

10. Lazo G, Kantarjian H, Estey E, Thomas D, O'Brien S and Cortes J: Use of arsenic trioxide (As2O3) in the treatment of patients with acute promyelocytic leukemia. Cancer 97: 2218-2224, 2003.

11. Hoonjan M, Jadhav V and Bhatt P: Arsenic trioxide: Insights into its evolution to an anticancer agent. J Biol Inorg Chem 23: 313-329, 2018

12. Abudoureyimu A and Muhemaitibake A: Arsenic trioxide regulates gastric cancer cell apoptosis by mediating cAMP. Eur Rev Med Pharmacol Sci 21: 612-617, 2017.
13. Sadaf N, Kumar N, Ali M, Ali V, Bimal S and Haque R: Arsenic trioxide induces apoptosis and inhibits the growth of human liver cancer cells. Life Sci 205: 9-17, 2018.

14. Woo SH, Park IC, Park MJ, Lee HC, Lee SJ, Chun YJ, Lee SH, Hong SI and Rhee $\mathrm{CH}$ : Arsenic trioxide induces apoptosis through a reactive oxygen species-dependent pathway and loss of mitochondrial membrane potential in HeLa cells. Int J Oncol 21: 57-63, 2002.

15. Kizildag S, Ates H and Kizildag S: Treatment of K562 cells with 1,25-dihydroxyvitamin D3 induces distinct alterations in the expression of apoptosis-related genes BCL2, BAX, BCLXL, and p21. Ann Hematol 89: 1-7, 2010.

16. Bae JY, Kim JW and Kim I: Low-dose 1,25-dihydroxyvitamin $\mathrm{D}(3)$ combined with arsenic trioxide synergistically inhibits proliferation of acute myeloid leukemia cells by promoting apoptosis. Oncol Rep 30: 485-491, 2013.

17. Pozarowski P and Darzynkiewicz Z: Analysis of cell cycle by flow cytometry. Methods Mol Biol 281: 301-311, 2004.

18. Livak KJ and Schmittgen TD: Analysis of relative gene expression data using real-time quantitative PCR and the 2(-Delta Delta C(T)) method. Methods 25: 402-408, 2001.

19. Deeb KK, Trump DL and Johnson CS: Vitamin D signalling pathways in cancer: Potential for anticancer therapeutics. Nat Rev Cancer 7: 684-700, 2007.

20. Krishnan AV, Trump DL, Johnson CS and Feldman D: The role of vitamin D in cancer prevention and treatment. Endocrinol Metab Clin North Am 39: 401-418, 2010.

21. Peery RC, Liu JY and Zhang JT: Targeting survivin for therapeutic discovery: Past, present, and future promises. Drug Discov Today 22: 1466-1477, 2017.

22. Mobahat M, Narendran A and Riabowol K: Survivin as a preferential target for cancer therapy. Int J Mol Sci 15: 2494-2516, 2014.

23. Friedrichs B, Siegel S, Andersen MH, Schmitz N and Zeis M: Survivin-derived peptide epitopes and their role for induction of antitumor immunity in hematological malignancies. Leuk Lymphoma 47: 978-985, 2006.

24. Li N, Guan X, Li F, Li X and Chen Y: Vorinostat enhances chemosensitivity to arsenic trioxide in K562 cell line. Peer J 3: e962, 2015.

c) (i) $($ This work is licensed under a Creative Commons Attribution-NonCommercial-NoDerivatives 4.0 International (CC BY-NC-ND 4.0) License. 